\title{
PREOCUPĂRI PRIVIND CONSERVAREA ENERGIEI ȘI MEDIULUI ÎN REGLEMENTĂRI TEHNICE ELABORATE ÎN UAUIM
}

\author{
CONCERNS OF ENERGY AND ENVIRONMENTAL \\ CONSERVATION IN THE TECHNICAL REGULATIONS \\ DRAFTED AT UAUIM
}

prof. dr. arh./prof. PhD arch. Ana-Maria Dabija*, prof. dr. ing./ prof. PhD eng. Radu Petrovici

Universitatea de Arhitectură și Urbanism "Ion Mincu"/ Centrul de Studii Arhitecturale și Urbane "Ion Mincu"University of Architecture and Urbanism / Center for Architectural and Urban Studies *am.dabija@uauim.ro 



\title{
Rezumat
}

Elaborarea reglementărilor tehnice pentru proiectarea şi execuţia construcţiilor, constituie o procupare continuă, împreună cu activitatea didactică, pentru majoritatea cadrelor didactice din UAUIM.

Pentru domeniile specifice care constituie tema acestui Simpozion, comunicarea prezintă două reglementări tehnice elaborate şi aprobate în ultimii ani. Reglementările conţin principii şi prevederi generale de alcătuire şi de calcul şi numeroase detalii de execuţie pentru subiectele respective astfel încât pot fi folosite nemijlocit în proiectare şi în execuţie.

Este subliniată, pentru fiecare dintre cele două procedee tehnologice, necesitatea aplicării unitare şi controlate a tehnologiilor adecvate, verificate de practica unor ţări avansate.

Comunicarea are ca scop informarea participanţilor la Simpozion asupra obiectului, scopului şi conţinutului celor două reglementări menţionate mai sus, elaborate la UAUIM.

Cuvinte cheie: reglementări tehnice, fațade,vegetaţie, cerințe

\begin{abstract}
Drafting of the technical regulations for building design and execution is a continuous concern, alongside the academic activity, for the majority of UAUM professors.

For the two specific areas that constitute the theme of this Symposium, the paper presents two technical regulations drafted and approved in the last years. The regulations include general principles and provisions for architectural and structural planning, calculation methods and numerous construction details for the subjects in question, so they can directly be used in design and execution.

For each of the two technological procedures, the need for uniform and controlled application of the appropriate technologies, verified by the practice of other countries, is emphasized.

The paper aims to inform the participants to the Symposium on the object, purpose and content of the two regulations mentioned above, drafted at UAUIM.
\end{abstract}

Keywords: technical regulations, façades, vegetation, requirements 


\section{Introducere}

Iniţiatorii şi elaboratorii celor două reglementări tehnice, care fac obiectul prezentei comunicări, au pornit de la ideea că, alături de activitatea curentă, didactică şi de cercetare, au şi obligaţia morală de a folosi cunoştinţele lor pentru a sprijini, în mod concret, progresul profesiunii de constructor şi prin aceasta, activitatea profesională a colegilor arhitecţi şi ingineri.

Elaborarea, comentarea şi detalierea reglementărilor tehnice pentru unele procedee şi tehnologii moderne de construcţie, utilizate intens în prezent în ţări avansate, reprezintă materializarea acestei concepţii.

In text sunt prezentate două reglementări tehnice elaborate în UAUIM privind:

- Proiectarea faţadelor cu alcătuire ventilată - indicativ NP 135-2013

- Proiectarea şi execuţia acoperişurilor verzi la clădiri noi şi existente - indicativ GP 1202013

Ambele reglementări au caracter complex, interdisciplinar, şi au devenit necesare pentru proiectarea şi execuţia în România a unor soluţii constructive moderne pentru acoperişurile şi faţadele clădirilor civile şi industriale. În raport cu soluţiile "tradiţionale", alcătuirile care fac obiectul celor două reglementări au particularităţi semnificative, care decurg din natura, calitatea şi dimensiunile materialelor folosite, din tehnologia şi precizia cerută execuţiei şi din condiţiile de întreţinere/exploatare. Acoperirea cerinţelor şi a condiţiilor tehnice pentru totalitatea parametrilor menţionaţi mai sus a necesitat din partea autorilor reglementărilor un efort important de sinteză şi de sistematizare. Evident, redactările actuale sunt perfectibile, ca rezultat al aplicării practice a versiunilor actuale, pentru un interval rezonabil de timp. În acest scop, autorii consideră utile şi aşteaptă toate observaţiile pertinente ale utilizatorilor.

Diversitatea aspectelor tehnice şi tehnologice abordate, a făcut necesară constituirea unor colective de redactare complexe, din care au făcut parte specialişti din mai multe ramuri ale construcţiilor (arhitecţi şi ingineri structurişti şi de instalaţii) dar şi din botanică şi ştiinţele solului (pentru acoperişurile verzi).

Reglementările au fost redactate folosind, în principal, formularea exigenţială, în conformitate cu toate cele şase cerinţe esenţiale din legea nr. 10/1995, care a fost în vigoare la data elaborării lor. Din acest motiv, autorii consideră că ambele reglementări necesită completări ca urmare a modificării Legii nr.10/1995, prin Legea nr.177/2015 prin care s-a introdus o cerinţă esenţială suplimentară Folosirea raţională (sustenabilă) a resurselor naturale.

La redactarea textelor s-a urmărit, în mod deosebit, rigurozitatea formulărilor teoretice şi precizarea/ilustrarea, cât mai completă a termenilor tehnici folosiţi prin introducerea în texte a glosarelor de termeni specifici şi a unui număr mare de desene care ilustrează diferite situaţii concrete din proiecte.

Textele sunt însoţite de comentarii şi exemplificări. Având în vedere caracterul de noutate al celor mai multe prevederi din cele două reglementări, considerăm necesară sporirea şi diversificarea acestora, într-un text separat sau la o ediţie ulterioară . În cazul faţadelor cu alcătuire ventilată, cu strat de placare din zidărie, considerăm necesară şi completarea Codului de proiectare CR 6-2013 cu un paragraf destinat alcătuirii şi calculului "Zidăriilor de placare" aşa cum există în reglementarea din USA (MSJC, 2013). 


\section{Introduction}

The initiators and authors of the two technical regulations, which are the subject of this paper, started from the idea that, along with the current teaching and research activity, they also have the moral obligation to use their knowledge to specifically support the progress of the builder profession and, thereby, the professional activity of architect and engineer colleagues.

The drafting, commenting and detailing of the technical regulations for various modern construction techniques and technologies, now widely used in advanced countries, is the materialization of this concept.

We present bellow two technical regulations on:

- Design of façades with ventilated structure - indicative NP 135-2013

- Design and execution of green roofs on new and existing buildings - indicative GP 120-2013

Both regulations have a complex, interdisciplinary nature, and have become necessary for the design and execution in Romania of modern constructive solutions for the roofs and façades of civil and industrial buildings. In relation to the "traditional" solutions, the parts of buildings that are the object of the two regulations have significant peculiarities that arise from the nature, quality and dimensions of the materials used, from the technology and precision required for the execution and from the maintenance/exploitation conditions. Meeting the requirements and technical conditions for all of the above-mentioned parameters, has required a significant effort of synthesis and systematization on the part of the authors of the regulations. Clearly, the draft can be perfected, as a result of the practical implementation of current versions, for a reasonable amount of time. To this effect, the authors find it useful and await all pertinent observations of the users.

The diversity of the technical and technological aspects approached made it necessary to set up complex editing teams, consisting of specialists from several branches of constructions (architects, structural and facilities engineers) but also from botany and soil sciences (for green roofs).

The regulations have been drafted using mainly the exigential concept in accordance with all six essential requirements of Law no. 10/1995, which was in force at the date of their drafting. For this reason, the authors believe that both regulations require additions as a result of the amendment of Law no. 10/1995, by Law no.177/2015, which introduced an essential additional requirement. Rational (sustainable) use of natural resources.

The drafting of the texts particularly aimed at the rigorousness of the theoretical formulations and the most complete specification/illustration of the technical terms used, by introducing, in the texts, the glossaries of specific terms and of a large number of drawings illustrating different practice situations in the projects.

Texts are accompanied by comments and exemplifications. Considering the new features of the two regulations, we believe it necessary to increase and diversify them, in a separate text or a subsequent edition. In the case of façades with ventilated structure, with a masonry veneer, we consider it necessary to complete the CR 6-2013 Design Code with a paragraph intended for the construction and calculation of "anchored veneers" as it exists in the US regulation (MSJC, 2013). 
Autorii prezentei comunicări subliniază faptul că performanţele în exploatare ale celor două alcătuiri constructive depind în foarte mare măsură de aplicarea corectă şi integrală a reglementărilor tehnice respective. Abaterile de la prevederile acestora şi/sau adoptarea unor rezolvări improvizate conduc, de cele mai multe ori, la realizarea unor construcţii de calitate necorespunzătoare, care nu satisfac una sau mai multe dintre cerinţele esenţiale.

\section{Reglementări internaţionale şi naționale}

Pentru ambele alcătuiri constructive menţionate mai sus, în prezent, sunt elaborate, la nivel internaţional, numai un număr redus de reglementări tehnice care pot fi considerate $\boldsymbol{d} \boldsymbol{e}$ referinţă. Majoritatea procedeelor folosite în proiectare (calcul şi detaliere) sunt promovate de diferite firme, pe baza studiilor proprii.

- În UE nu există reglementări complete pentru proiectarea faţadelor cu alcătuire ventilată. Sunt reglementate numai dispozitivele de prindere între straturi prin Agremente tehnice europene (ETA). În Franţa (prin NF DTU 20.1) şi în USA (prin MSJC 2013) sunt reglementate zidăriile de placare ancorate, prevederile respective fiind parţial aplicabile în cazul stratului de protecţie al faţadelor cu alcătuire ventilată.

- Proiectarea şi execuţia acoperişurilor verzi sunt reglementate în USA de mai multe texte dintre care cel mai cuprinzător este ASTM E2400 - 06 Standard Guide for Selection, Installation and Maintenance of Plants for Green Roof Systems.

- În UE nu există reglementări comunitare.

- In UK: Green Roofing Guidelines: 2008 Guidelines for the Planning, Construction and maintenance of green roofing

- În Germania FFL (Forschungsgesellschaft Landchaftsentwicklung Landschaftsbau e.V.) Forschungsgesellschaft Landschaftsentwicklung Landschaftbau's (German Landscape Research, Development and Construction Society).

- In Canada: Toronto municipal Code. Chapter 492, Green roofs.

\section{NORMATIV PENTRU PROIECTAREA FAŢADELOR CU}

\section{ALCĂTUIRE VENTILATĂ - NP 135-2013}

\subsection{Conţinutul normativului şi colectivul de elaborare}

Reglementarea este alcătuită din şapte capitole şi şase anexe, după cum urmează:

- Capitolul I Obiect şi domeniu de aplicare

- Capitolul II Terminologie

- Capitolul III Principii de conformare şi alcătuire pentru diferite alcătuiri de faţade ventilate

- Capitolul IV Materiale şi produse pentru componenta de protecţie - finisaj

- Capitolul V Condiţii tehnice pentru asigurarea performanţelor necesare, în raport cu cerinţele de calitate formulate în legea 10 / 1995, cu modificările ulterioare, la faţadele cu alcătuire ventilată

- Capitolul VI Condiţii de durabilitate şi întreţinere a faţadelor ventilate

- Capitolul VII Utilizarea sistemelor de faţade ventilate la clădiri existente

- Anexa 1 Referinţe tehnice şi legislative

- Anexa 2 Fişa tehnică de securitate (safety data sheet) 
The authors of this paper emphasize that the performances of the two constructive parts (facades and roofs) depend to a very large extent on the correct and complete application of the respective technical regulations. Deviations from their provisions and/or the adoption of improvised solutions most of the times lead to the construction of poor quality buildings that do not meet one or more of the essential requirements.

\section{International and national regulations}

For both building methods mentioned above, only a limited number of technical regulations are currently being developed at international level that can be considered of reference. The majority of techniques used in design (computation and detailing) are promoted by different firms based on own studies.

- In the $\mathbf{E} \mathbf{U}$, there are no complete regulations for the design of façades with ventilated structure. Only the ties between layers are provided by norms by the European Technical Agreements (ETA). In France (by NF DTU 20.1) and in USA (by MSJC 2013) the anchored brick veneers are stipulated, such provisions being partially applicable to the protective layer of façades with ventilated structure.

- The design and execution of green roofs are regulated in the USA by several texts, the most comprehensive of which is the ASTM E2400 - 06 Standard Guide for Selection, Installation and Maintenance of Plants for Green Roof Systems.

- There are no community regulations in the EU.

- In the UK: Green Roofing Guidelines: 2008 Guidelines for the Planning, Construction and maintenance of green roofing.

- In Germany FFL (Forschungsgesellschaft Landchaftsentwicklung Landschaftsbau e.V.) Forschungsgesellschaft Landschaftsentwicklung Landschaftbau's (German Landscape Research, Development and Construction Society).

- In Canada: Toronto municipal Code. Chapter 492, Green roofs.

\section{NORMATIVE FOR THE DESIGN OF VENTILATED FAÇADES - NP}

\section{5-2013}

\subsection{Content of the normative and drafting team}

The regulation consists of seven chapters and six annexes, as follows:

- Chapter I

Object and scope

- Chapter II

Terminology

- Chapter III

Principles of compliance and composition for different structures of ventilated façades

- Chapter IV Materials and products for the protective - finishing component

- Chapter V Technical conditions to ensure the required performance in relation to quality requirements formulated in Law 10/1995, as further amended, for façades with ventilated structure

- Chapter VI Conditions of sustainability and maintenance of ventilated façades

- Chapter VII Use of ventilated façade systems on existing buildings

- Annex 1 Technical and legislative references

- Annex 2 Safety Data Sheet 
- Anexa 3 Valorile limită maxime ale conţinutului de compuşi organici volatili pentru vopsele şi lacuri

- Anexa 4 Exemple de posibile restricţii în cazul materialelor pentru construcţii

- Anexa 5 Exemple de sisteme de faţade ventilate

- Anexa 6 Bibliografie

Normativul a fost elaborat de un colectiv numeros, în care au fost antrenaţi şi specialişti, din afara UAUIM, cunoscuţi pentru competenţa lor în domeniile respective:

- prof. dr. arh. Ana-Maria Dabija (coordonator)

- prof. dr. ing. Radu Petrovici (Rezistenţă şi stabilitate mecanică)

- prof. dr. ing. Viorica Demir - prof. dr. ing Mariana Stan (Protecţie la zgomot)

- drd. ing. Ovidiu Mihalache (Securitate la incendiu)

- $\quad$ prof. dr. ing. Horia Asanache (Umiditate)

- dr. ing. Adrian Ţabrea - ing. Monica Cherecheş (Izolaţie termică şi hidrofugă)

- ing. Victoria Baciu (Igienă, sănătate, mediu)

- conf. dr. arh. Crenguța Daniela Bratu care a coordonat o echipă de tineri asistenţi şi lectori doctoranzi şi doctori (Dan Mihai, Bogdan Bănică, Laura Buzatu, Anamaria Mortu, Ioana Șerbănescu, Oana Mihăescu) care au identificat exemple pentru pricipalele tipuri de sisteme de finisaj> lemn, metal, ceramică, piatră etc.

\subsection{Obiectul normativului}

Normativul NP 135-2013 detaliază măsurile specifice necesare pentru proiectarea, execuția și întreținerea faţadelor cu alcătuire ventilată prezentând principiile lor de alcătuire, domeniul de utilizare, condiţiile şi cerinţele specifice.

Prevederile acestei reglementări se aplică la proiectele noi de clădiri cu faţade ventilate, precum şi la proiectele de reabilitare a clădirilor existente, pentru care soluţia de reabilitare propusă este faţada ventilată.

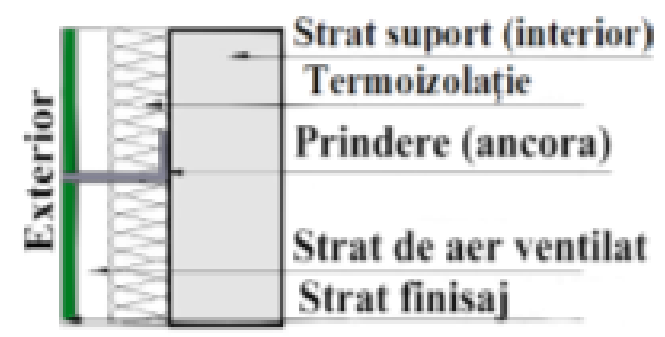

Fig. 1: Alcătuirea faţadelor ventilate (principiu)

Structure of ventilated façades (principle). Legend: Strat suport (interior) $=$ layer (interior) $/$ Termoizolaţie $=$ Thermal insulation $/$ Prindere $=$ Fixture $($ anchor $) /$ Strat de aer ventilat $=$ Ventilated air layer $/$ Strat finisaj $=$ Finishing layer

Denumirea faţadă cu alcătuire ventilată este folosită pentru sistemul de închidere la care una dintre componente este prevăzută cu o lamă de aer ventilată natural (slab sau puternic).

Stratul suport poate fi element de construcţie structural sau nestructural (de exemplu, zidărie înrămată într-un cadru de beton armat/oţel).

Pentru componentele de protecţie şi finisaj se folosesc diferite tipuri de materiale tradiţionale În text sunt enumerate, separat, şi produse uzuale pentru plăci de finisaj, din diferite materiale tradiţionale 
- Annex 3 Maximum limit values for the volatile organic compounds content for paints and varnishes

- Annex 4 Examples of possible restrictions on building materials

- Annex 5 Examples of ventilated façade systems

- Annex 6 Bibliography

The normative has been drafted by a large team, involving specialists from outside the UAUIM, known for their competence in the respective fields:

- Prof. PhD. Arch. Ana-Maria Dabija (coordinator)

- Prof. PhD. Eng. Radu Petrovici (Mechanical resistance and stability)

- Prof. PhD. Eng. Viorica Demir - Prof. PhD. Eng. Mariana Stan (Protection to noise)

- PhD. c. Eng. Ovidiu Mihalache (Fire Safety)

- $\dagger$ Prof. PhD. Eng. Horia Asanache (Humidity)

- PhD. Eng. Adrian Țabrea - Eng. Monica Cherecheş (Thermal and Waterproof Insulation)

- $\quad$ Eng. Victoria Baciu (Hygiene, Health, Environment)

- Assist. Prof. PhD. Arch. Crenguța Daniela Bratu who coordinated a team of young PhD c. and $\mathrm{PhD}$ assistants and lecturers (Dan Mihai, Bogdan Bănică, Laura Buzatu, Anamaria Mortu, Ioana Șerbănescu, Oana Mihăescu) who provided examples for the main types of finishing systems $>$ wood, metal, ceramics, stone etc

\subsection{Aim of the Normative}

The NP 135-2013 normative details the specific measures required for the design, execution and maintenance of façades with ventilated structure presenting their construction principles, scope of use, specific conditions and requirements.

The provisions of this regulation apply to new projects of buildings with ventilated façades, as well as to rehabilitation projects of existing buildings, for which the proposed rehabilitation solution is the ventilated façade.

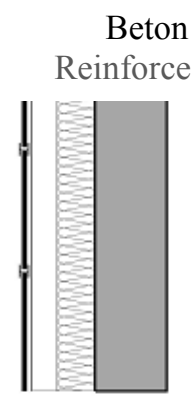

Beton armat

Reinforced concrete

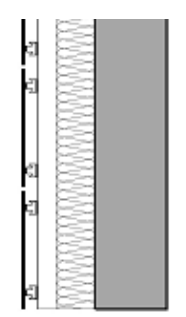

Elemente ceramice Ceramic Elements

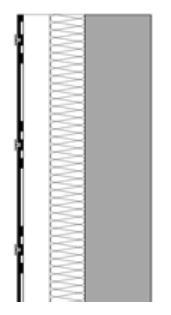

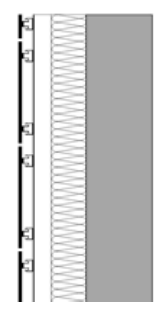

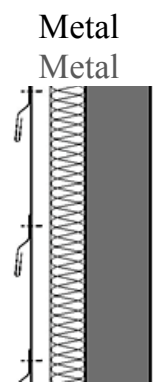

Fig. 2: Materiale tradiţionale pentru stratul de protecţie/finisaj Traditional materials for the protective/finishing layer

The name of façades with ventilated structure is used for the closing system where one of the components is provided with a naturally ventilated (weak or strong) air blade.

The support layer may be a structural or non-structural building element (for example, masonry infilled in a reinforced concrete/steel frame).

Various types of traditional materials are used for the protection and finishing components

The text also separately lists, customary products for finishing panels of different traditional materials 


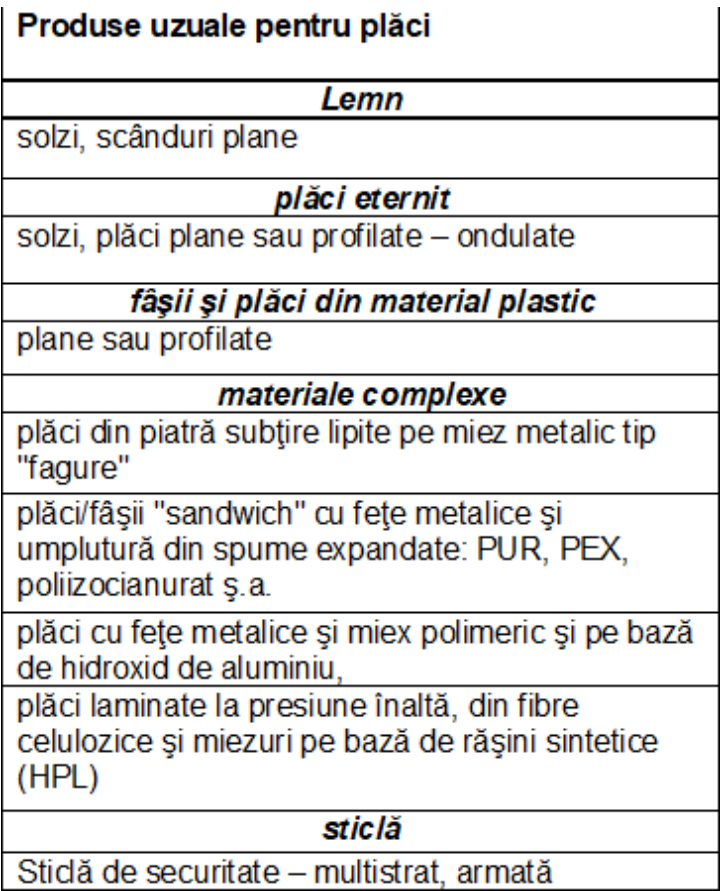

\begin{tabular}{l}
\hline \multicolumn{1}{c|}{ piatră naturală } \\
\hline marmură, granit, calcar... \\
\hline \multicolumn{1}{c|}{ piatră reconstituită } \\
\hline aglomerate cu rășini sintetice \\
\hline \multicolumn{1}{c|}{ piatră artificială } \\
\hline $\begin{array}{l}\text { arsă } \\
\text { plăci ceramice din gresie porţelanată } \\
\text { nearsă } \\
\text { prefabricate din similipiatră } \\
\text { prefabricate din beton }\end{array}$ \\
\hline \multicolumn{1}{c|}{ metal } \\
\hline $\begin{array}{l}\text { plăci din tablă plană, ambutisată, oțel vopsit } \\
\text { otelel corten,aluminiu }\end{array}$ \\
\hline $\begin{array}{l}\text { plăci din tablă profilată, cutată, ondulată,oțel } \\
\text { aluminiu }\end{array}$ \\
\hline elemente liniare profilate \\
\hline $\begin{array}{l}\text { panouri din tablă de aluminiu ambutisată sau cu } \\
\text { schelet propriu, cu miez "fagure" și faţă din foi de } \\
\text { tablă }\end{array}$
\end{tabular}

Normativul permite realizarea componentei de protecţie folosind şi materiale neconvenţionale :

- $\quad$ Materialele compozite, formate din două sau mai multe materiale, care duc la formarea unui material cu caracteristici diferite faţă de materialele constituente în parte.

- $\quad$ PVC folosit în general ca înlocuitor pentru lemn.

- $\quad$ Sisteme vii :

- Pereţi vii (living walls): sisteme de structuri susţinute pe faţadele clădirilor în care sunt fixate containere cu mediul de creștere şi plante.

- Faţade verzi (green facades): faţade pe care se ridică plante căţărătoare.

Legăturile între straturi (prinderile) asigură stabilitatea stratului exterior şi transmiterea încărcărilor aplicate pe acesta la stratul suport.

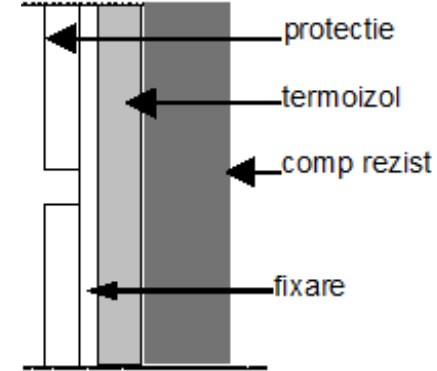

Fixare în puncte izolate Anchorage in isolated points

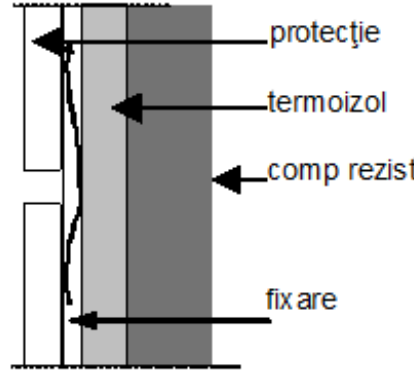

Fixare continuă Continuous anchorage

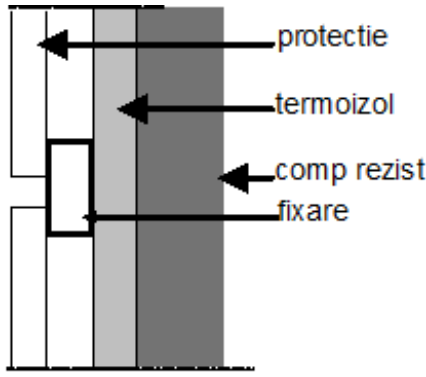

Fixare la reazem Anchorage on bracket

Fig. 3: Fixarea stratului de protecție pe stratul suport (principii)

Anchorage of the protection layer on the support layer (principles). Legend: protectie = protection / termoizol. $=$ thermal insulation $/$ comp. rezist. $=$ backup wall $/$ fixare $=$ anchorage 


\begin{tabular}{|c|c|}
\hline Customary products for panels & Customary products for panels \\
\hline Wood & natural stone \\
\hline tiles, flat planks & marble, granite, limestone \\
\hline eternit panels & reconstructed stone \\
\hline tiles, flat or corrugated panels & agglomerate with synthetic resins \\
\hline complex materials & artificial stone \\
\hline $\begin{array}{l}\text { thin stone slabs stuck on "honeycomb" } \\
\text { metal core }\end{array}$ & \multirow{2}{*}{$\begin{array}{c}\text { burnt } \\
\text { porcelain slate ceramic tiles } \\
\text { unburned } \\
\text { gravel plastering prefabricates } \\
\text { concrete precast }\end{array}$} \\
\hline $\begin{array}{c}\text { "sandwich" panels/strips with metallic sides } \\
\text { and expanded foam fillings: PUR, PEX, } \\
\text { polyisocyanurate, a.o. }\end{array}$ & \\
\hline $\begin{array}{l}\text { panels with metallic sides and polymer } \\
\text { core and aluminium hydroxide based }\end{array}$ & metal \\
\hline $\begin{array}{l}\text { high pressure laminated sheets, of cellulose } \\
\text { fibres and synthetic resin based cores (HPL) }\end{array}$ & $\begin{array}{l}\text { panels made of flat, pressed metal, } \\
\text { painted steel, corten steel, aluminium }\end{array}$ \\
\hline glass & $\begin{array}{c}\text { panels made of profiled, cut, corrugated, } \\
\text { aluminium steel }\end{array}$ \\
\hline multi-layer - reinforced security glass & linear profiled elements \\
\hline & $\begin{array}{c}\text { panels of pressed aluminium or with own } \\
\text { frame, with "honeycomb" core and sheet } \\
\text { metal sides }\end{array}$ \\
\hline
\end{tabular}

The normative allows the execution of the protective component using nonconventional materials, as-well:

- Composite materials, made of two or more materials, which lead to the formation of a material with characteristics different from the constituent materials, individually.

- $\quad$ PVC, generally used as wood substitute.

- $\quad$ Living systems:

- Living walls: systems of structures supported on the façades of buildings where containers with the growing environment and plants are fitted.

- Green façades: façades on which climbing plants are growing.

The connections between the layers (fixtures) ensure the stability of the outer layer and the transmission of the loads applied to it, to the support layer.

1

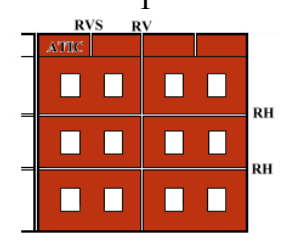

2

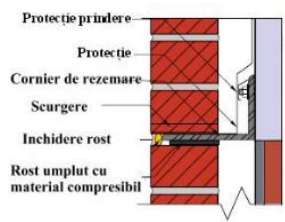

3

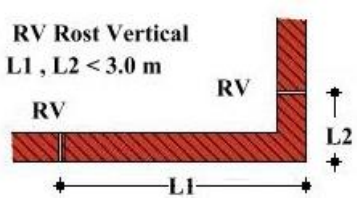

4

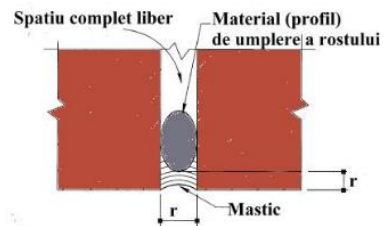

Fig. 4: Detalii rosturi în stratul de protecţie din zidărie

1- Amplasarea rosturilor 2- Detaliu rost orizontal 3- Amplasare rosturi verticale 4- Închidere rost vertical Details for joints in the protection layer in the masonry

1- Placement of joints 2 - Detail of horizontal joint 3 - Placement of vertical joints 4 - Detail of vertical joint Legend: Protecție de prindere $=$ Anchorage protection $/$ Protecție $=$ Protection $/$ Cornier de rezemare $=$ Shelf angle support $/$ Scurgere $=$ Weep hole $/$ Inchidere rost $=$ Joint closing $/$ Rost umplut cu material compresibil $=$ Joint filled with compressible material $/$ Rost vertical $=$ Vertical joint $/$ Spatiu complet liber $=$ Completely free space $/$ Material (profil) de umplere a rostului $=$ Backer rod $/$ Mastic $=$ Sealant 
Deoarece stratul de finisaj/protecţie este expus direct variaţiilor de temperatură/umiditate se prevăd rosturi de "deplasare", verticale (RV) şi orizontale (RH).

Pentru alegerea raţională a materialelor pentru faţadele cu alcătuire ventilată, reglementarea recomandă să se ţină seama de mai multe criterii:

- Concepţia şi cerinţele specifice ale proiectului de arhitectură

- Satisfacerea cerinţelor de performanţă în condiţii de cost total minim pe durata de exploatare prevăzută prin tema de proiectare (durabilitatea) .

- Condiţiile de agresivitate ale mediului natural şi antropic:

- agresivitatea mediului natural (salinitatea în zona litoralului, de exemplu)

- agresivitatea mediului antropic înconjurător provenită din:

$\checkmark$ poluarea urbană;

$\checkmark$ degajări agresive în zonele industriale.

\subsection{Cerinţe de performanţă}

Reglementarea formulează explicit condiţii tehnice de proiectare specifice pentru satisfacerea tuturor cerinţelor esenţiale. Dintre acestea exemplificăm:

- Sub efectul acţiunii vântului sau a cutremurului, faţadele cu alcătuire ventilată trebuie să satisfacă următoarele cerinţe:

- Siguranța vieții: reducerea riscului de punere în pericol a integrităţii fizice a oamenilor prin căderea, în spaţiile publice (în stradă, de exemplu) sau în spaţiile în care se pot afla mai multe persoane (curţile interioare ale şcolilor, de exemplu), a elementelor stratului exterior (de finisaj).

- Limitarea degradărilor: reducerea costurilor pentru repararea faţadelor ventilate avariate de cutremur precum şi a pierderilor cauzate de întreruperea temporară a activităţii normale în clădire ca urmare a avarierii faţadei.

- Conformarea la foc a pereţilor exteriori ai clădirilor, în funcţie de rolul acestora, trebuie să îndeplinească condiţiile minime de rezistenţă la foc pentru încadrarea în nivelul respectiv de stabilitate la foc conform Normativului P118.

- Produsele cu rol preponderent termic trebuie să răspundă şi la alte cerinţe: absorbţie acustică, igienă, sănătate, protecţie a mediului înconjurător, comportare la difuzia vaporilor, comportare sub acţiunea focului, caracteristici ecologice şi durabile.

Reglementarea conţine un număr mare de planşe cu detalii de asamblare şi montaj care pot fi utilizate direct pentru redactarea proiectelor de execuţie.

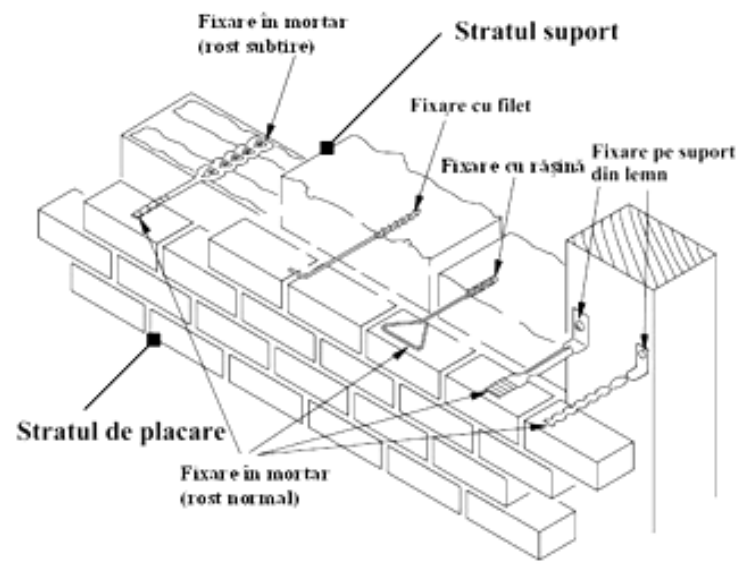

Fig. 5a: Detalii de execuţie. Ancore conform SR EN 845

Execution details. Anchors compliant with SR EN 845. Legend: Stratul support $=$ Support layer $/$ Stratul de placare $=$ veneer $/$ Fixare în mortar (rost subțire) $=$ Mortar anchoring (thin joint) / Fixare cu filet $=$ Fillet anchoring $/$ Fixare cu răşină $=$ Resin anchoring $/$ Fixare pe support din lemn $=$ Anchorage on wood support / Fixare în mortar $($ rost normal $)=$ Mortar anchoring $($ normal joint $)$ 
Because the protection/finishing layer is directly exposed to the temperature/humidity variations, vertical (RV) and horizontal (RH) "sliding" joints are provided.

For the rational choice of materials for ventilated façades, the regulation recommends taking into consideration several criteria:

- Concept and specific requirements of the architectural project

- Meeting the performance requirements under minimum total cost conditions during the operational life provided by the design theme (sustainability).

- Conditions of the natural and anthropic environment:

- severity of exposure to the natural aggresive environment (salinity in the coastal area, for example)

- severity of exposure to the anthropic aggresive environment originating from:

$\checkmark$ urban pollution;

$\checkmark$ aggressive releases in industrial areas.

\subsection{Performance requirements}

The regulation explicitly formulates specific design technical conditions to meet all the essential requirements. Here are some examples:

- Under the effect of wind or earthquake action, the façades with ventilated structure must meet the following requirements:

- Safety of life: reducing the risk of endangering the physical integrity of people by collapsing in public spaces (in the street, for example) or in places where several people can be present (inner courtyards of schools, for example), of elements of the outer (finishing) layer.

- Limiting degradation: reducing costs for repairing ventilated façades damaged by earthquake, as well as losses caused by the temporary disruption of normal activity in the building as a result of damage to the façade.

- Compliance to fire of the exterior walls of the buildings, depending on their role, must meet the minimum fire resistance conditions for being classified in the respective fire stability level according to P118 Normative.

- Products with a predominantly thermal role must meet other requirements, as well: acoustic absorption, hygiene, health and environmental protection, vapour diffusion behaviour, behaviour under fire, ecological and sustainable features.

The regulation contains a large number of green roofs assemblies and execution details that can be used directly for drafting the execution projects.

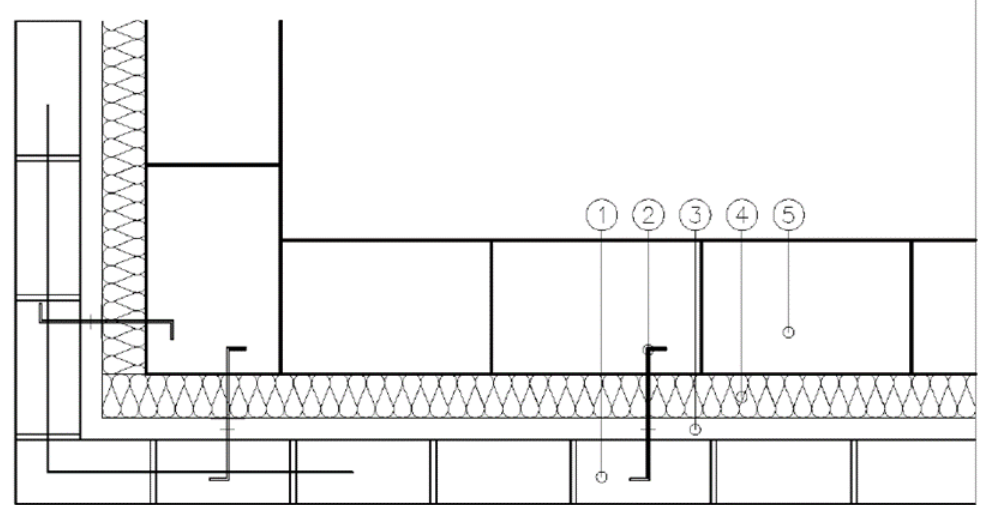

Fig. 5b: Detalii de execuţie. Strat placare CERAMICA

Execution details. CERAMICA cladding layer
1. Protection and finishing component

2. The fastening and assembly component

3. Ventilated air layer

4. Thermo-insulating componen

5. Resistance component 


\subsection{Cerinţe de durabilitate}

Având în vedere dificultăţile tehnice şi costurile ridicate legate de înlocuirea stratului de protecţie Normativul impune măsuri speciale pentru asigurarea durabilităţii acestuia; aceste măsuri sunt diferenţiate în funcţie de clasele de expunere în care se pot afla faţadele. Exemplificăm aceste măsuri pentru cazul stratului de placare din zidărie:

- Clase de expunere (situaţii curente):

$\checkmark$ Clasa de expunere MX3.1. Pereţi exteriori adăpostiţi de streaşini sau atice înclinate, care nu sunt expuşi la scurgeri severe de apă

$\checkmark$ Clasa de expunere MX3.2. Pereţi exteriori cu piese de acoperire sau cu streaşini drepte expuşi la scurgeri severe de apă.

- Alegerea elementelor pentru zidărie şi a mortarelor
$\checkmark$ Clasa de expunere MX3.1. $\rightarrow$ Elemente F1 sau F2/S1 sau S2
$\checkmark$ Clasa de expunere MX3.2. $\rightarrow$ Elemente F2/S1 sau S2
$\checkmark$ Clasa de expunere MX3.1. $\rightarrow$ Mortar M sau S
$\checkmark$ Clasa de expunere MX3.2 $\rightarrow$ Mortar S

Definirea elementelor şi a mortarelor din punct de vedere al durabilităţii este dată în Codul CR6-2013.

Pentru ancorele metalice protecţia anticorosivă se realizează conform standardului SR EN 845-1. În absenţa protecţiei adecvate condiţiilor reale de expunere, se produce reducerea secţiunii ancorelor urmată, de regulă de desprinderea stratului de protecţie.
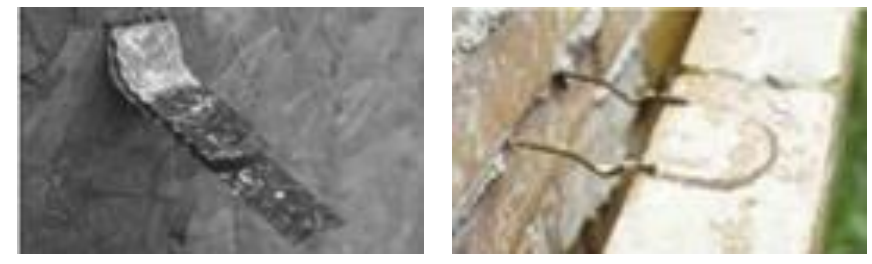

Fig. 6a: Ancore avariate prin coroziune

Anchors damaged by corrosion

\section{GHID PRIVIND PROIECTAREA ŞI EXECUŢIA ACOPERIŞURILOR VERZI LA CLĂDIRI NOI ŞI EXISTENTE -GP 120-2013}

\subsection{Conţinutul reglementării şi colectivul de elaborare}

Reglementarea este alcătuită din zece capitole şi şapte anexe, după cum urmează:

- Capitolul 1 - Obiect şi domeniu de aplicare

- Capitolul 2 - Terminologie

- Capitolul 3 - Elemente generale de proiectare a acoperişurilor verzi

- Capitolul 4 - Analiza straturilor specifice ale învelitorilor verzi

- Capitolul 5 - Prevederi specifice pentru acoperişuri plate şi în pantă

- Capitolul 6 - Proiectarea acoperişurilor verzi din punct de vedere al cerinţei de rezistenţă mecanică şi stabilitate

- Capitolul 7 - Proiectarea acoperişurilor verzi din punct de vedere al cerinţelor esenţiale

- Capitolul 8 - Precizări privind execuţia acoperişurilor verzi

- Capitolul 9 - Consideraţii economice

- Capitolul 10 - Amenajarea acoperişurilor verzi pe clădiri existente 


\subsection{Durability Requirements}

Given the technical difficulties and the high costs related to the replacement of the protective layer, the Normative requires special measures to ensure its durability; such measures are differentiated depending on the exposure classes of the façades. We exemplify these measures for the masonry cladding:

- Exposure Classes (current situations):

$\checkmark$ Exposure class MX3.1. Exterior walls sheltered by inclined eaves or attics that are not exposed to severe water flow.

$\checkmark$ Exposure class MX3.2. Exterior walls with coverings or straight eaves exposed to severe water flow.

- Choice of masonry units and mortars
$\checkmark$ Exposure class MX3.1. $\rightarrow$ Units F1 or F2/S1 or S2
$\checkmark$ Exposure class MX3.2. $\rightarrow$ Units F2/S1 or S2
$\checkmark$ Exposure class MX3.1. $\rightarrow$ Mortar M or S
$\checkmark$ Exposure class MX3.2 $\rightarrow$ Mortar S

Masonry units and mortars are specified for durability using the terms defined in Code CR6-2013.

For metal anchors, the corrosion protection systems is ensured according to SR EN 8451 standard. In the absence of the protection adequate to the actual exposure conditions, the reduction of the section of the anchors occurs, usually followed by the premature cracking and, finally, by the colapse of the protective layer (veneer).
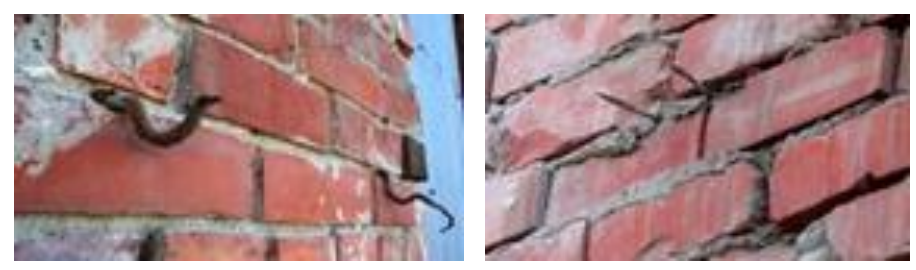

Fig. 6b: Ancore avariate prin coroziune

Anchors damaged by corrosion

\section{GUIDE TO THE DESIGN AND EXECUTION OF GREEN ROOFS FOR NEW AND EXISTING BUILDINGS - GP 120-2013}

\subsection{Regulation Content and Drafting Team}

Regulation consists of ten chapters and seven annexes, as follows:

- Chapter 1 - Object and scope

- Chapter 2 - Terminology

- Chapter 3 - General design elements for green roofs

- Chapter 4 - Analysis of specific layers of green coverings

- Chapter 5 - Specific provisions for flat or slope roofs

- Chapter 6 - Design of green roofs in terms of mechanical strength and stability

- Chapter 7 - Designing green roofs in terms of essential requirements

- Chapter 8 - Specification for the execution of the green roofs

- Chapter 9 - Economic considerations

- Chapter 10 -Projects of green roofs on existing buildings 
- Anexa 1 - Vegetaţia României

- Anexa 2 - Plante, substraturi, cerinţe ecologice

- Anexa 3 - Exemple de reţete şi plante în funcţie de substraturi

- Anexa 4 - Dicţionar de termeni botanici

- Anexa 5 - Evaluare consumuri suplimentare de materiale pentru structura acoperişului

- Anexa 6 - Detalii de alcătuire

- Anexa 7 - Comentarii

Normativul a fost elaborat de un colectiv în care au fost antrenaţi şi specialişti din USAMV Bucureşti cunoscuţi pentru competenţa lor în domeniile respective (botanica, ştiinţele solului):

- prof. dr. arh. Ana-Maria Dabija

- prof. dr. ing. Radu Petrovici

- conf. dr. ing. Mihaela Ioana Georgescu

- drd. arh. Dan Mihai

- $\quad$ arh. Eugen Popescu (colaborare la capitolele 2, 3, 4)

Consultant pentru cerinţa "Securitate la incendiu": arh. Nina Munteanu

\subsection{Obiectul reglementării}

Ghidul detaliază condiţiile şi măsurile specifice necesare pentru proiectarea acoperişurilor verzi, la clădiri noi şi la clădiri existente.

Sunt furnizate prevederi pentru proiectarea, execuţia şi întreţinerea acoperişurilor verzi cu forme plate şi în pantă şi sunt detaliate principiile de alcătuire pentru trei categorii de vegetaţie (conform International Green Roofs Association):

- Acoperiş verde extensiv: tip de acoperiş verde pentru care nu este necesară luarea unor măsuri speciale pentru creşterea şi dezvoltarea plantelor; aceste plante sunt adaptate unor condiţii extreme de mediu. Ele sunt ierburi, muşchi, plante suculente, unele tipuri de plante cu bulbi sau tuberculi (Figura 7a)

- Acoperiş verde semi-extensiv: tip de acoperiş verde în care plantele (ierburi, tufe, plante perene) necesită luarea unor măsuri reduse pentru întreţinere (udare, îngrăşăminte). Aceste plante necesită o grosime mai mare de pământ decât în cazul învelitorilor extensive (Figura 7b)

- Acoperiş verde intensiv (terasă grădină): tip de acoperiş verde, plat, în care plantele (ierburi, tufe, arbuşti, copaci, anuale sau perene) sunt plantate urmărind aceleaşi condiţii (specifice) de plantare ca şi pe sol. Condiţiile de creştere şi dezvoltare sunt particulare şi aceste tipuri de plante necesită îngrijire (udare regulată şi fertilizare corespunzătoare). Stratul de pământ în care se plantează are caracteristici speciale şi grosime importantă. (Figura 7c)

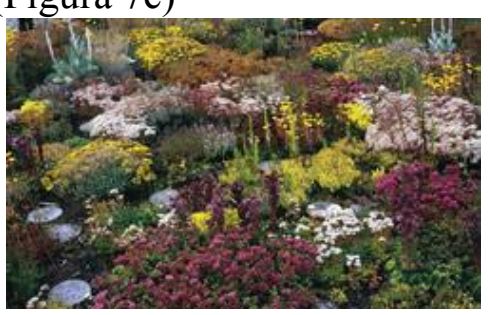

(a)

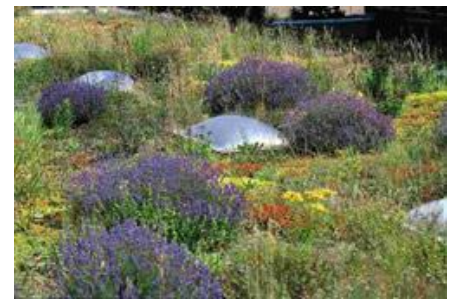

(b)

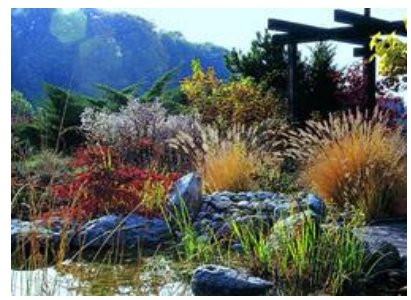

(c)

Fig. 7: Tipuri de vegetaţie (http://www.igra-world.com)

Types of vegetation 
- Annex 1 - Vegetation of Romania

- Annex 2 - Plants, substrates, ecological requirements

- Annex 3 - Examples of recipes and plants depending on substrates

- Annex 4 - Dictionary of botanical terms

- Annex 5 - Evaluation of additional of materials for the roof structure

- Annex 6-Structure details

- Annex 7 -Comments

The normative has been drafted by a team involving, as well, specialists from USAMV Bucharest known for their competence in the respective fields (botany, soil sciences):

- Prof. PhD. Arch. Ana-Maria Dabija

- Prof. PhD. Eng. Radu Petrovici

- Assist.Prof. PhD. Eng. Mihaela Ioana Georgescu

- PhD. c. Arch. Dan Mihai

- Arch. Eugen Popescu (collaboration in chapters 2, 3, 4)

Consultant for the "Fire Safety" requirement: Arch. Nina Munteanu

\subsection{Regulation Object}

The guide details the specific conditions and measures needed to design green roofs in new buildings and in existing buildings.

Provisions are provided for the design, execution and maintenance of flat and sloped green roofs and the composition principles for three categories of vegetation (according to International Green Roofs Association) are detailed:

- Extensive green roof: type of green roof for which no special measures are necessary for growing and developing plants; these plants are adapted for extreme environmental conditions. They consist of herbage, moss, succulent plants, some types of bulb or tubercle plants (Figure 7a)

- Semi-extensive green roof: a type of green roof where plants (herbage, bushes, perennials) require minimal measures for maintenance (watering, fertilizers). These plants require a thicker layer of soil than in the case of extensive coverings (Figure 7b)

- Intensive green roof (garden terrace): a green, flat roof type in which plants (herbage, bushes, shrubs, trees, annuals or perennials) are planted following the same (specific) planting conditions as on soil. Growth and development conditions are particular and these types of plants require care (regular watering and proper fertilization). The soil layer in which they are planted has special features and a significant thickness. (Figure $7 \mathrm{c})$

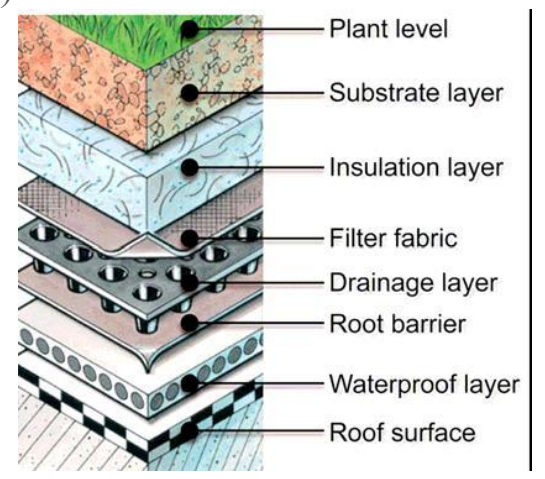

Strat vegetal

Substrat

Izolaţie

Strat filtrant

Strat drenant

Barieră contra rădăcinilor

Hidroizolaţie

Suprafaţa acoperişului

Fig. 8: Succesiunea straturilor la acoperişuri verzi (Gartner, 2008)

Succession of layers in green roofs 


\subsection{Alcătuirea generală a acoperişurilor verzi}

Ghidul precizează materialele şi succesiunea straturilor din care sunt alcătuite acoperişurile verzi:

- Elementul suport al sistemului termo-hidro-izolant se execută din aceleaşi materiale ca şi în cazul acoperişurilor normale: beton armat, lemn , metal ;

- Izolaţiile termice se realizează din plăci cu caracteristici diferite de rezistenţă/rigiditate:

1. Plăci rezistente, de exemplu, plăci din sticlă spongioasă ş.a.

2. Plăci semirezistente (elastice), de exemplu, polistiren expandat sau extrudat, poliuretan rigid, plută aglomerată, plăci de vată minerală cu densitate mai mare de 100 $\mathrm{kg} / \mathrm{mc}$ ş.a

3. Plăci moi, de exemplu: plăci ,rigide” din vată minerală (densitate mai mică de $100 \mathrm{~kg} / \mathrm{mc})$.

- Hidroizolaţiile pot fi bituminoase sau polimerice, sub formă de membrane sau pelicule aplicate in situ;

Succesiunea straturilor componente ale acoperişurilor verzi (amplasate deasupra plăcii peste ultimul nivel) este stabilită astfel (de sus în jos): strat vegetal, substrat, izolaţie, strat filtrant, strat drenant, barieră contra rădăcinilor, hidroizolaţie, suprafaţa acoperişului (Fig. 8).

\subsection{Proiectarea pentru cerinţa REZISTENŢĂ MECANICĂ ŞI STABILITATE}

Având în vedere faptul că straturile de cultură aduc încărcări semnificative pe acoperişul clădirii, decizia de a realiza un acoperiş verde trebuie să fie fundamentată în mod obiectiv, prin evaluarea consumurilor suplimentare de materiale în raport cu soluţia acoperişului "clasic". În cazul în care acoperişul verde urmează a se realiza pe o clădire existentă decizia se ia pe baza unei expertize tehnice prin care se determină capacitatea disponibilă a structurii

Conform acestui Ghid, proiectarea pentru cerinţa de rezistenţă şi stabilitate implică parcurgerea următoarelor etape:

- Stabilirea concepţiei de conformare arhitectural-structurală

- Identificarea factorilor care intervin la proiectarea structurală a clădirilor cu acoperişuri verzi pe baza conceptului de stări limită

- Calculul efectelor structurale ale încărcărilor suplimentare date de acoperişurile verzi (identificarea consumuri suplimentare de materiale)

- Evaluarea siguranţei structurale a clădirilor cu acoperişuri verzi

- Proiectarea clădirilor cu acoperişuri verzi pentru durabilitate.

\subsection{Diagrame pentru proiectare (exemplu)}

Pentru a facilita evaluarea sporului de încărcare pe acoperiş $\left(\boldsymbol{\rho}_{a v}\right)$ în funcţie de tipul vegetaţiei, fără calcule detaliate, în Ghid sunt date mai multe diagrame care pot fi folosite cu suficientă precizie în acest scop. 


\subsection{General structure of green roofs}

The guide specifies the materials and the succession of the layers which the green roofs consist of:

- The support element of the thermo-hydro-insulating system is executed from the same materials as normal roofs: reinforced concrete, wood, metal;

- Thermal insulations are made of panels with different strength/stiffness characteristics:

4. Resistant panels, for example, porous glass panels, a.o.

5. Semi-resistant panels (elastic), for example, expanded or extruded polystyrene, rigid polyurethane, agglomerated cork, mineral wool slabs with a density greater than 100 $\mathrm{kg} / \mathrm{m}^{3}$ a.o.

6. Soft panels, for example: "rigid" panels of mineral wool (density less than $100 \mathrm{~kg} / \mathrm{m}^{3}$ ).

- Waterproofing may be bituminous or polymeric, in the form of membranes or films applied in situ.

The succession of the component layers of the green roofs (placed above the panel over the last level) is set forth as follows (from top to bottom): plant level, substrate layer, insulation layer, filter fabric, drainage layer, root barrier, waterproof layer, roof surface (Fig. 8).

\subsection{Design for the MECHANICAL RESISTANCE AND STABILITY requirement}

Considering that the culture layers bring significant load on the roof of the building, the decision to build a green roof must be objectively substantiated, by assessing the additional quantities of materials in relation to the "classic" roof solution. If the green roof is to be built on an existing building, the decision is based on a technical expertise that determines the capacity of the structure.

According to this Guide, designing for the resistance and stability requirement involves covering the following steps:

- Establishing the architectural and structural general concept

- Identifying the factors involved in the structural design of green roofs based on the concept of limit states

- Calculation of the structural effects of additional loads created by green roofs (identification of additional quantities of materials)

- Assessing the structural safety of buildings with green roofs

- Designing buildings with green roofs for durability.

\subsection{Design Charts (example)}

In order to facilitate the assessment of the load increase on the roof $\left(\boldsymbol{\rho}_{\boldsymbol{a}}\right)$ dependant on the type of vegetation, without detailed calculations, several diagrams are given in the Guide which can be used with sufficient precision to this purpose. 


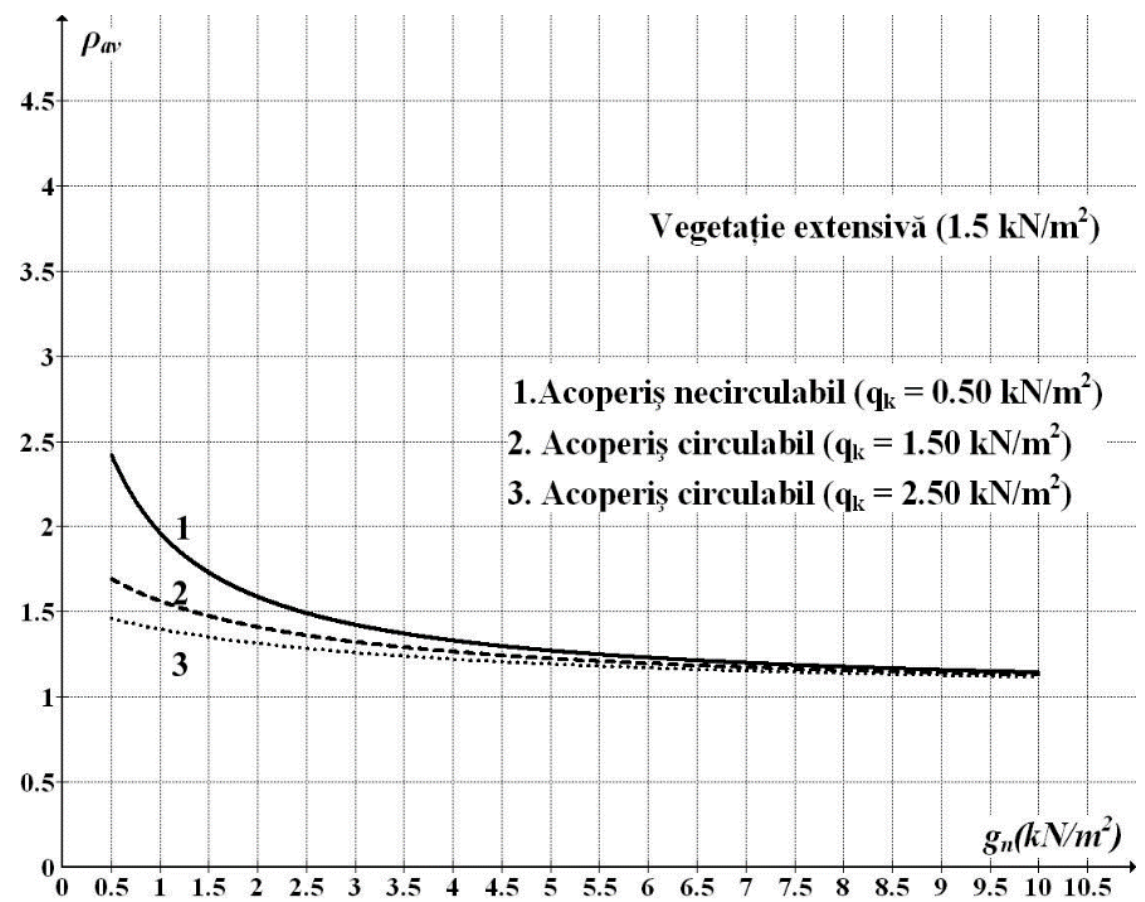

Fig. 9a: Grafic pentru determinarea sporului de încărcare pe acoperiş în funcţie de tipul vegetaţiei - vegetaţie extensivă

Chart for determining the load increase on the roof, dependant on the type of vegetation - Extensive

vegetation. Legend: Acoperiș necirculabil $=$ Roof not accessible to the public $/$ Acoperiș circulabil $=$ Roof accessible to the public

În graficele de mai sus s-a notat:

- $\quad g_{n}$ - valoarea caracteristică a încărcării permanente (în $\mathrm{kN} / \mathrm{m}^{2}$ )

- $\boldsymbol{q}_{\boldsymbol{k}}$ - valoarea caracteristică a încărcării utile (în $\mathrm{kN} / \mathrm{m}^{2}$ )

Din examinarea acestor grafice rezultă următoarele concluzii care sunt utile pentru adoptarea deciziei de executare a acoperişurilor verzi:

a. Diferenţele de încărcare totală de proiectare între acoperişurile cu vegetaţie extensivă şi cele cu vegetaţie semi-intensivă sunt importante numai pentru acoperişurile necirculabile uşoare ( $\mathrm{cu} \boldsymbol{g}_{\boldsymbol{n}} \leq 2.5 \mathrm{kN} / \mathrm{m}^{2}$ ); în celelalte cazuri valorile sporurilor de încărcare sunt practic similare (de ordinul a $20 \div 30 \%$ faţă de acoperişurile cu alcătuire normală).

b. Ponderea sporului de încărcare adus de vegetaţia de tip intensiv este deosebit de mare pentru acoperişurile uşoare (orientativ, cu încărcarea de proiectare $\boldsymbol{g}_{\boldsymbol{n}} \leq 2.5 \mathrm{kN} / \mathrm{m}^{2}$ ) indiferent de valoarea de proiectare a încărcării utile. Valorile cele mai mari se înregistrează în cazul acoperişurilor necirculabile. Ca atare, sporurile de cost vor fỉ de asemenea importante în special în cazul clădirilor cu număr mic de niveluri. Pe astfel de acoperişuri se recomandă adoptarea vegetaţiei extensive sau semi-intensive.

c. Pentru acoperişurile grele (acoperişurile din beton armat ale clădirilor cu încărcarea de proiectare $\left.\boldsymbol{g}_{\boldsymbol{n}} \geq 10 \mathrm{kN} / \mathrm{m}^{2}\right)$ sporurile de solicitare sunt modice $(\sim+20 \div 30 \%)$ şi, în cazul clădirilor cu mai multe niveluri, sporul costului total raportat la toate planşeele, scade odată cu numărul de niveluri al clădirii. 


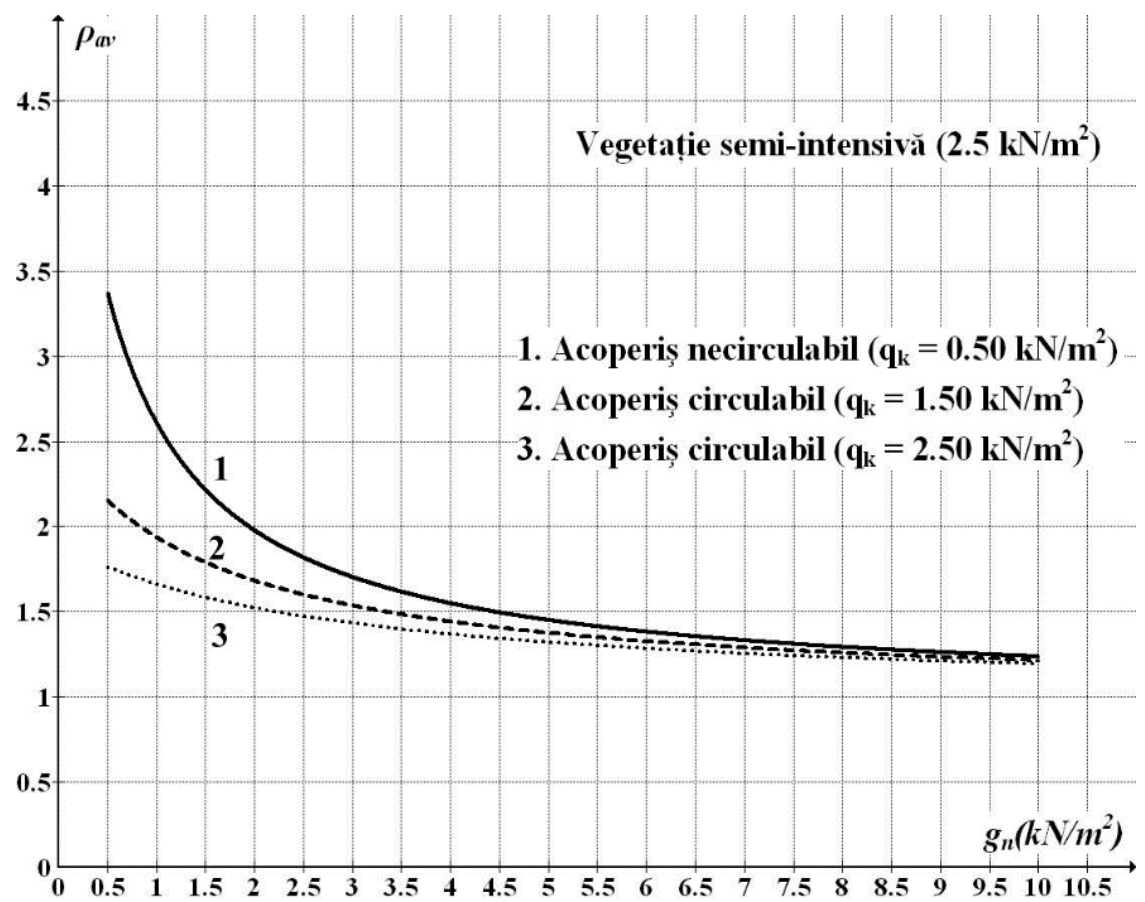

Fig. 9b: Grafic pentru determinarea sporului de încărcare pe acoperiş în funcţie de tipul vegetaţiei - vegetaţie extensivă

Chart for determining the load increase on the roof, dependant on the type of vegetation - Semi-extensive vegetation. Legend: Acoperiș necirculabil = Roof not accessible to the public $/$ Acoperiș circulabil $=$ Roof accessible to the public

The charts above noted:

- $\boldsymbol{g}_{\boldsymbol{n}}$ - characteristic value of the dead load (in $\mathrm{kN} / \mathrm{m}^{2}$ )

- $\boldsymbol{q}_{k}$ - characteristic value of the live load (in $\mathrm{kN} / \mathrm{m}^{2}$ )

By examining these charts, the following conclusions result that are useful for the adoption of the decision to execute the green roofs:

a. Total design load differences between roofs with extensive vegetation and those with semi-intensive vegetation are important only for lightweight roofs, not accessibles to the public (with $\mathbf{g}_{\mathbf{n}} \leq 2.5 \mathrm{kN} / \mathrm{m} 2$ ); in the other cases, the values of load increases are virtually similar (of the order of $20 \div 30 \%$ compared to roofs with normal structure).

b. The load increase caused by the intensive type vegetation is particularly high for light roofs (indicatively, with design load $\boldsymbol{g}_{\boldsymbol{n}} \leq 2.5 \mathrm{kN} / \mathrm{m}^{2}$ ) irrespective of the design value of the live load. The highest values are recorded for roofs not accessibles to the public. As such, cost increases will also be significant, especially for low-level buildings. On such roofs it is recommended to adopt the extensive or semi-intensive vegetation.

c. For heavy roofs (reinforced concrete roofs of buildings with the design load $\boldsymbol{g}_{\boldsymbol{n}} \geq 10$ $\left.\mathrm{kN} / \mathrm{m}^{2}\right)$, the stress increases are modest $(\sim+20 \div 30 \%)$ and, in the case of multi-level buildings, the increase in the total cost on all floors, decreases with the number of levels of the building. 


\subsection{Proiectarea acoperişurilor verzi din punct de vedere al cerinţei esenţiale de SECURITATE LA INCENDIU}

Se consideră că acoperişurile verzi intensive nu sunt sensibile la scântei şi sunt rezistente la radiaţia termică. Datorită stratului gros de pământ $(>20 \mathrm{~cm})$ şi faptului că sunt udate cu regularitate, ele pot fi considerate acoperişuri fără pericol de incendiu.

Acoperişurile verzi extensive sunt considerate rezistente la scântei şi la radiaţia termică dacă sunt îndeplinite unele condiţii speciale de alcătuire enumerate în text. Pentru produsele folosite la acest tip de acoperiş este necesară efectuarea de încercări privind clasele de performanţă la foc în condiţii de utilizare finală, pentru fiecare caz în parte.

4.7. Proiectarea acoperişurilor verzi din punct de vedere al cerinţei esenţiale de IGIENĂ, SĂNĂTATE ŞI MEDIU

În România nu există măsurători care să cuantifice beneficiile acoperişurilor verzi din punct de vedere al cerinţei esenţiale de igienă, sănătate, mediu. În aceste condiţii, în textul Ghidului se enunţă numai aprecieri calitative:

- Plantele consumă bioxid de carbon şi eliberează oxigen, contribuind astfel la asigurarea unui aer mai curat. Datorită fenomenului de evapo-transpiraţie, aerul din vecinătatea acoperişurilor verzi este mai rece şi mai umed, fapt care conduce şi la filtrarea şi depunerea prafului.

- Prin reducerea pierderilor de căldură din clădire şi ca urmare a fenomenului de evapotranspiraţie se reduce efectul de insule de căldură din mediul urban.

- Crearea de acoperişuri verzi în spaţiul urban presupune şi asigurarea bio-diversităţii.

- Acoperişurile verzi asigură, pe lângă funcţiunea de "plămân verde" al oraşului, şi zone posibile de loisir pentru comunitatea care utilizează clădirea respectivă.

\subsection{Proiectarea acoperişurilor verzi din punct de vedere al cerinţei esenţiale de PROTECŢIE LA ZGOMOT}

Substratul şi stratul vegetal reprezintă o masă suplimentară care contribuie la creşterea izolaţiei la zgomot aerian a spaţiilor de sub acoperiş.

Notă: Experimental s-a constatat că acoperişurile verzi extensive asigură o reducere suplimentară a nivelului de zgomot aerian cu $2-8 \mathrm{~dB}$ cu în gama de frecvenţe înalte şi cu 5 - 13dB în gama de frecvenţe medii şi joase (50 $2000 \mathrm{~Hz}$ ), în funcţie de alcătuirea (grosime, materiale) straturilor acoperişului verde, faţă de reducerea nivelului de zgomot aerian asigurată de stratul suport.

\subsection{Proiectarea acoperişurilor verzi din punct de vedere al cerinţei esenţiale de ECONOMIE DE ENERGIE ŞI IZOLARE TERMICĂ}

Acoperişurile verzi contribuie la reducerea consumurilor de energie şi a costurilor de combustibil. Substratul şi stratul vegetal asigură răcire - vara - şi izolare termică - iarna - pentru apartamentele situate sub acoperiş.

Vegetaţia şi substratul acesteia contribuie la întârzierea eliminării apei de pe suprafețele acoperişului şi implicit reduc presiunea apei de ploaie asupra dispozitivelor de scurgere a apelor pluviale, de la acoperiş la sistemul de canalizare.

Notă: Un substrat cu grosimea de $20-40 \mathrm{~cm}$ poate reţine o cantitate de $10-15 \mathrm{~cm}$ de apă, ceea ce reprezintă o reducere a debitului cu $25 \%$. 


\subsection{Design of green roofs in terms of the essential requirement of FIRE SAFETY}

Intensive green roofs are considered not to be spark sensitive and are resistant to thermal radiation. Due to the thick layer of soil $(>20 \mathrm{~cm})$ and the fact that they are regularly watered, they can be considered as fire hazard free roofs.

Extensive green roofs are considered to be spark-proof and resistant to thermal radiation if special structural conditions listed in the text are met. For products used in this type of roof, it is necessary to perform tests on the fire performance classes under final conditions of use, for each individual case.

\subsection{Design of green roofs in terms of the essential HYGIENE, HEALTH AND ENVIRONMENT requirement}

There are no measurements in Romania to quantify the benefits of green roofs in terms of the essential hygiene, health and environment requirement. Under such conditions, only qualitative assessments are given in the text of the Guide:

- Plants consume carbon dioxide and release oxygen, therefore helping to provide cleaner air. Due to the phenomenon of evaporation of exudation, the air in the vicinity of the green roofs is colder and more humid, which also leads to filtration and precipitation of dust.

- By reducing the heat loss in the building and as a result of the phenomenon of evaporation of exudation, the effect of heat islands in the urban area is reduced.

- Creating green roofs in the urban areas also involves ensuring biodiversity.

- Green roofs provide, besides the "green lung" function of the city, also possible leisure areas for the community using the respective building.

\subsection{Design of green roofs in terms of the essential NOISE PROTECTION requirement}

The vegetal substrate and layer constitute an additional mass that contributes to the increased insulation to airborne noise of the under-roof areas.

Note: Experimentally, it was observed that the extensive green roofs provide an additional reduction of the level of airborne noise by $2-8 \mathrm{~dB}$, in the high frequency range, and by $5-13 \mathrm{~dB}$, in the medium and low frequency range $(50-2000 \mathrm{~Hz})$, depending on the composition (thickness, materials) of the green roof layers, relative to the reduction of the level of airborne noise provided by the support layer.

\subsection{Design of green roofs in terms of the essential ENERGY ECONOMY AND THERMAL INSULATION requirement}

Green roofs contribute to reducing energy consumption and fuel costs. The vegetal substrate and layer provide cooling - in summer - and thermal insulation - in winter - for the apartments located under the roof.

The vegetation and its substrate contribute to delaying water drainage from roof surfaces and implicitly reduce rainwater pressure on rainwater drainage systems, from the roof to the sewerage system.

Note: A substrate having a thickness of $20-40 \mathrm{~cm}$ can retain a quantity of $10-15 \mathrm{~cm}$ of water, which constitutes a $25 \%$ reduction in flow. 


\subsection{Prevederi specifice pentru acoperişuri în pantă}

Ghidul prevede că pentru acoperişul cu panta mai mare de $10^{0}(18 \%)$ trebuie luate măsuri de stabilizare a straturilor componente. Pericolul de eroziune a substratului creşte odată cu creşterea pantei şi trebuie asigurată protecţia acestuia.

- Pentru acoperişurile verzi în pantă va fi prevăzută o hidroizolaţie performantă bituminoasă sau polimerică (termoplastice sau elastice). Primul strat hidroizolant trebuie să fie fixat mecanic, la pas de $5-10 \mathrm{~cm}$.

- Pentru hidroizolaţiile montate pe suport din lemn este necesară prevederea unui strat de separare realizat din ţesătură de fibră de sticlă, împâslitură din fibre poliesterice între suportul din lemn (astereala) şi hidroizolaţie.

- Se recomandă ca bariera contra rădăcinilor de sine stătătoare să fie prevăzută numai dacă panta învelitorii este sub $10^{0}(17,6 \%)$

\section{Concluzii}

In text sunt prezentate două reglementări tehnice elaborate în UAUIM privind:

- Proiectarea faţadelor cu alcătuire ventilată - indicativ NP 135-2013

- Proiectarea şi execuţia acoperişurilor verzi la clădiri noi şi existente - indicativ GP 1202013

Ambele reglementări au caracter complex, interdisciplinar, şi au devenit necesare pentru proiectarea şi execuţia în România a unor soluţii constructive moderne pentru acoperişurile şi faţadele clădirilor civile şi industriale. În raport cu soluţiile "tradiţionale", alcătuirile care fac obiectul celor două reglementări au particularităţi semnificative, care decurg din natura, calitatea şi dimensiunile materialelor folosite, din tehnologia şi precizia cerută execuţiei şi din condiţiile de întreţinere/exploatare.

\section{Referințe/References}

*** ASTM E2400 - 06 Standard Guide for Selection, Installation and Maintenance of Plants for Green Roof Systems.

*** MSJC Building Code Requirements and Specification for Masonry Structures, 2013

*** UK Guidelines for the Planning, Construction and maintenance of green roofing 2008

*** Toronto municipal Code. Chapter 492, Green roofs

Gartner, M. Structural Implications of Green Roofs, Terraces, and Walls, SEAOC 2008 Convention Proceedings

\section{Referinţe web/Web references}

International Green Roofs Association http://www.igra-world.com 


\subsection{Specific provisions for sloped roofs}

The guide provides that for roofs with a slope greater than $100(18 \%)$, actions must be taken to stabilize the component layers. The risk of erosion of the substrate increases as the slope increases and its protection must be ensured.

- For sloped green roofs, a bituminous or polymeric (thermoplastic or elastic) highquality waterproofing will be provided. The first waterproofing layer must be mechanically fixed at a $5-10 \mathrm{~cm}$ interval.

- For waterproofing mounted on wood support, it is necessary to provide a separating layer made of fibreglass fabric, polyester fibre felt between the wooden support (lath) and waterproofing.

- It is recommended that the root-barrier be provided only if the cover slope is below $10^{0}$ $(17.6 \%)$

\section{Conclusions}

This article presents two technical regulations elaborated at UAUIM:

- Design of façades with ventilated structure - indicative NP 135-2013

- Design and execution of green roofs on new and existing buildings - indicative GP 120-2013

Both regulations have a complex, interdisciplinary nature, and have become necessary for the design and execution in Romania of modern constructive solutions for the roofs and façades of civil and industrial buildings. In relation to the "traditional" solutions, the parts of buildings that are the object of the two regulations have significant peculiarities that arise from the nature, quality and dimensions of the materials used, from the technology and precision required for the execution and from the maintenance/exploitation conditions. 